\title{
Modern regulatory and legal regulation of the peasant (farmer) economy: problems of theory and practice
}

\author{
Oksana Grechenkova ${ }^{1, *}$ \\ ${ }^{1}$ Institute of Service and Entrepreneurship (branch) of DSTU in Shakhty, str., 147, 346500 Shevchenko, \\ Russia
}

\begin{abstract}
The article is devoted to the topic "Modern regulatory and legal regulation of the peasant (farmer) economy: problems of theory and practice". The article examines the legal framework of peasant (farmer) farming in the Russian Federation including in the south of Russia and the Rostov region. The issues of regulating the activities and support of the peasant (farmer) economy are relevant, since regulation is associated with the development of new technologies, increasing the level of mechanization, professional and legal culture of rural residents. The peculiarities of the functioning of farms give reason to talk about the need to clarify legal information, including regional information. The modern problems of the normative-legal regulation of the activity of the peasant (farmer) economy, both from the theoretical and practical points of view, are determined.
\end{abstract}

\section{Introduction}

The Constitution of the Russian Federation and the Civil Code of the Russian Federation regulate the ownership, use and disposal of land and other natural resources, as well as issues of peasant (farmer) farming. In particular, citizens who conduct joint activities in the field of agriculture without forming a legal entity on the basis of an agreement on the establishment of a peasant (farmer) farm have the right to create a legal entity - a peasant (farmer) farm. The Federal Law "On Peasant (Farm) Farming" defines the legal, economic and social foundations for the establishment and operation of peasant (farm) farms. The law guarantees the right of citizens to establish peasant (farm) farms and their independent activities.

Federal scientific and technical program for the Development of Agriculture for 2017 2025 is designed to ensure a stable growth in the production of agricultural products obtained through the use of seeds of new domestic varieties and breeding products( material), technologies for the production of high-quality feed, feed additives for animals and medicines for veterinary use, pesticides and agrochemicals of biological origin, processing and storage of products, raw materials and food, modern diagnostic tools, quality control methods and expertise of genetic material. Among other things it is planned to attract investments in the agro-industrial complex; to create and implement technologies for the production of seeds of

*Corresponding author: grechenkovak@mail.ru 
the highest categories (original and elite) of agricultural plants, breeding products (material) in the areas of domestic crop production and animal husbandry, which currently have a high degree of dependence on seeds or breeding products (material) of foreign production.

Many organizations and automated data processing systems are engaged in the analysis of logistics (ALS) of high-tech equipment. Therefore, the initial data and the results of the analysis should be presented in a standardized form. This requires an integrated information model that describes all relevant data elements, their attributes, and their relationships. In ALS, the tools that control the operation of high-tech equipment are an important component of the information system [1].

During the past 10 years the agrifood sector has become a very serious area of economic growth in the country. In the world this sector of the economy attracts more and more investment and there are many technological solutions and changes in this area, especially in such areas as genetics, breeding, IT technologies and artificial intelligence. There are many innovations in various approaches to production, these are organic products, eco, bio and green brands. In this connection there are different legal approaches and attitudes to the requirements for agricultural production.

The purpose of the study is to analyze the regulatory and legal regulation of the activities of the peasant (farmer) economy, both at the federal level and at the regional level, to identify problems and find ways to solve them.

Rapid identification of innovative opportunities and their implementation by enterprises through the qualitative use of human and intellectual capital can lead the enterprise to an innovative development model [2].

The fragmentation of legal scientific research on the subject, the lack of adequate state policy in the sphere of agricultural activity, providing balance social and economic interests, the lack of a comprehensive regulation of farming in the current legislation, conflict of laws civil and agrarian legislation, the lack of a conceptual model of legal regulation of farming activities, taking into account Russian historical and legal traditions and foreign, make the subject relevant and in demand.

The Deputy Chairman of the Russian Security Council Dmitry Medvedev called the problems in Russian agriculture that need to be solved in order to ensure the country's food security.

"It is not surprising that foreign seed material is much more in demand among our farmers than domestic... This is directly contrary to the principles established by the doctrine. Therefore, we need to think about how to centralize the work on seed selection: from scientific development to their introduction into production, " Medvedev said during a meeting on the implementation of the provisions of the food security doctrine of the Russian Federation. He added that this problem may be the most difficult, "We do not succeed."

The theoretical and methodological basis of the study was the research of foreign and domestic scientists. The study uses a dialectical method that allows us to trace the provisions of the civil legislation of the Russian Federation. The legal (dogmatic) method is also used which makes it possible to study the norms of civil law through their interpretation by theoretical scientists, to formulate prospects for the development of peasant (farmer) farming, both at the federal and regional levels. This method allows us to identify the differences and features of the application of federal and regional norms, in particular, the normative legal acts of the Rostov region.

As a result of the analysis of the regulatory and legal regulation of the activities of the peasant (farmer) economy at the present stage of development, we make the conclusion that there is insufficient legal regulation, both at the federal and regional levels. The lack of additional incentives for the younger generation to engage in agricultural activities, to replace the outgoing generation, leads to the lack of implementation of these norms in practice. Innovative activities that could find application in the activities of the peasant (farmer) 
economy are practically absent (introduction of new technologies, product quality management, digitalization, creation of new types of products). The Civil Code of the Russian Federation does not set strict deadlines for the implementation of all procedures for the registration of intellectual property objects. There is a large proportion of subjectivism which creates prerequisites for the pursuit of personal (public servants) and private (economic entities) benefits in addition to or instead of national-state and public benefits, which are aimed at extracting the activities of, in this case, the peasant (farmer) economy. This makes it expedient to conduct intersectoral economic and legal research that initiates the further formation of the legal sphere of innovative activity with anti-criminogenic potential [3].

Special attention should be paid to agriculture and fishing.

Their role as a neutralizer of overall risk is entirely due to the negative covariance of their returns with those of other industries in other regions. At the same time, these industries themselves show the lowest levels of yield volatility, which also affects the risk assessment [4].

\section{Methods and subject of the study.}

The methodological basis is a systematic approach which focuses the study on the study of the peasant (farmer) economy as an integral complex, which allows us to determine not only the basis of regulatory regulation, but also its effectiveness. A systematic approach allows us to see the existence of investment problems, difficulties in obtaining state support.

Consideration of the problems of regulatory regulation of the peasant (farmer) economy caused the need to involve the methods of the structural and functional approach. The tools for identifying the specifics of the selected object were the comparative-historical and comparative-comparative methods, which allow to identify and compare the levels in the development of the studied problem, possible investment problems, to reveal the content of regulatory regulation, comparing federal and regional Russian legislation.

\section{Identification of problems and ways to solve them.}

Peasant (farm) economy is a type of business activity and an association of citizens who jointly own property and carry out production or other economic activities. After the state registration of a peasant farm its head is an individual entrepreneur-farmer. The property of a farm belongs to its members on the right of joint ownership.

The legal nature of the regulation of the peasant (farmer) economy has been reported since 1989 after the proclamation of the agrarian and land reform by the state. Now agricultural practice differs from the Soviet standards. Firstly, technologically and secondly, the approach of working in state-owned collective farms and modern business farms is fundamentally different, and thirdly the legal regulation has become more progressive and requires knowledge not only in the field of agriculture but also in economics, management and law.

The property of a farm may include:

- land plot, household and other buildings;

- reclamation and other structures;

- productive working cattle, poultry;

- agricultural and other equipment;

- equipment, vehicles, inventory.

All the listed property must be properly registered as a property, a long-term lease usually with the use of borrowed funds. 
The problem is that there is no legal possibility to take out a subsidized loan if a legal entity or a peasant (farmer) farm has been registered for less than one year. Incoherent support is almost useless, as it requires insurance of crops, herds which negates all its advantages. The lack of additional incentives for the younger generation to conduct agricultural activities, to replace them, leads to the lack of implementation of these norms in practice. The decrease in the number of farms is accompanied by an increase in the area per farm, that is, they are being enlarged with a further transition to other forms of management.

The difficulties of farmers due to the coronacrisis are associated not only with objective factors but also with management errors. Imports take up a lot of space in the cost of agricultural products. These are, for example, spare parts for tractors starting from the crankshafts and ending with small gaskets for milking machines, other imported equipment. Farmers also buy seeds, live animals, incubator eggs of all types of poultry for breeding. In this regard, there is a need to recreate the state breeding centers, so that there is no need for purchases abroad. Quarantine restrictions due to the coronavirus also caused damage to agriculture.

In the southern Russian regions, for example, in the Krasnodar territory, the Rostov region there were introduced the very strict isolation measures and many agricultural producers faced difficulties in transportation. These restrictions created additional problems for farmers during the sowing campaign. Everything was organized inefficiently and to get a pass for the passage of agricultural machinery it was necessary to spend time and this increased costs and resulted in an increase in prices for manufactured products.

Because of the coronavirus the logistics chains of movement from the field to the plate were disrupted. They were especially noticeably interrupted between private producers and small markets, because the latter were closed. It was impossible to trade either in a mask or without a mask. Some have started to switch to online trading, where the seller and the buyer agree on a deal in advance on the Internet. The quarantine affected the implementation of agreements between producers of early vegetables and buyers from other regions.

Assistance from the state is subject to various conditions. To get it in a drought, there must be a large percentage of the affected areas. Due to the" coronavirus " problems agriculture has been on the periphery of public attention this year.

First of all the sources of regulation of this industry are the legislation of the Russian Federation. The legislation of the Russian Federation comprises the Constitution of the Russian Federation, the Civil code of the Russian Federation, Federal law "On peasant (farm)", decrees of the Government of the Russian Federation, decrees of the Government of the Rostov region, the scientific and technical program of development of agriculture for the 2017 - 2025" and other documents .

\section{The results of the study.}

The Constitution of the Russian Federation (article 36) states that citizens and their associations have the right to own land in private ownership. Ownership, use and disposal of land and other natural resources are carried out freely by their owners if this does not cause damage to the environment and does not violate the rights and legitimate interests of other persons. The conditions and procedure for the use of land are determined on the basis of federal law.

The Civil Code of the Russian Federation in article 86.1. regulates the issues of peasant (farmer) farming. In particular citizens who conduct joint activities in the field of agriculture without forming a legal entity on the basis of an agreement on the establishment of a peasant (farmer) farm (article 23) have the right to create a legal entity - a peasant (farmer) farm.

A peasant (farmer) farm established in accordance with this article as a legal entity is a voluntary association of citizens on the basis of membership for joint production or other 
economic activities in the field of agriculture, based on their personal participation and the association of property contributions by members of the peasant (farmer) farm.

The property of a peasant (farmer) farm belongs to him by right of ownership.

A citizen may be a member of only one peasant (farmer) farm established as a legal entity.

Foreclosure lenders peasant (farmer) households land owned households land subject to sale at public auction in favor of a person who in accordance with law shall be entitled to continue to use the land for the intended purpose.

Members of a peasant (farmer) farm established as a legal entity bear subsidiary responsibility for the obligations of the peasant (farmer) farm.

The specifics of the legal status of a peasant (farmer) farm established as a legal entity are determined by law.

The Federal Law "On Peasant (Farm) Farming" defines the legal, economic and social foundations for the establishment and operation of peasant (farm) farms. The law guarantees the right of citizens to establish peasant (farm) farms and their independent activities.

Chapter 1 "General Provisions" contains the definition of a peasant (farmer) economy, which is understood as an association of citizens related by kinship and (or) property, having property in common ownership and jointly carrying out production and other economic activities (production, processing, storage, transportation and sale of agricultural products), based on their personal participation. A farm can be created by one citizen.

The farm carries out business activities without forming a legal entity. Peasant (farmer) farms established as legal entities in accordance with the Law of the RSFSR of November 22, 1990 No. 348-I "On Peasant (Farmer) Farms" had the right to retain the status of a legal entity for the period up to January 1, 2010.

In Chapter 2, "Creating a farm", the requirements for creating a farm are formulated. Chapter 3 "Farm property" defines its composition and the conditions for its possession, use and disposal. Chapter 4 defines the legal status of land plots granted and acquired for the establishment of a farm and the procedure for carrying out its activities. Chapter 5 sets out the procedure for the admission of new members to the farm and the termination of membership, as well as the rights, duties and powers of the head of the farm. Chapter 6 is devoted to the definition of the types of activities of the farm. The main activities of the farm are the production and processing of agricultural products, as well as the transportation (transportation), storage and sale of agricultural products of its own production. Chapter 7 establishes the possibility of combining farms. Chapter 8 defines the procedure for termination of farming.

In accordance with paragraph 3 of Article 1 of the Federal Law of June 11, 2003 No. 74FZ "On Peasant (Farmer) Farming", a peasant (farmer) farm (hereinafter referred to as a farm) carries out business activities without forming a legal entity. Such a farm is considered established in accordance with Article 5 of the said Federal Law from the date of its state registration in accordance with the procedure established by the legislation of the Russian Federation.

Paragraph 2 of the resolution of the RF Government dated 16 October 2003, No. 630 is established that state registration of KFKH is carried out in the manner prescribed for state registration of physical persons as individual entrepreneurs. The head of a farm that operates without forming a legal entity is recognized as an entrepreneur from the moment of state registration of the farm (paragraph 2 of Article 23 of the Civil Code of the Russian Federation).

From paragraph 3 of Article 8 of Federal Law No. 129-FZ of August 08, 2001 "On State Registration of Legal Entities and Individual Entrepreneurs" (hereinafter - the Law on State Registration), it follows that the state registration of a farm should be carried out at the place of residence of its head. 
State registration of KFKH authorized to implement the Federal tax service of Russia (item 1 of the decree of the RF Government dated may 17, 2002 № 319, § 15 of the decree of the President of the Russian Federation from 09 March 2004 No. 314 "About system and structure of Federal Executive bodies").

For the state registration of a farm to the registration authority in accordance with paragraph 1 of Article 22.1 of the Law on State Registration, it is necessary, in particular, to submit:

- signed by the applicant application for state registration in the form P21002, approved by MHC of the Russian Federation from 03 December 2003 № BG-3-09/664. The applicant, under paragraph 1 of article 9 of the Law on the state registration, clause 2, article 23 of the Civil code of the Russian Federation, the head of KFKH the authenticity of the signature on the application must be notarised;

- a copy of the passport of the head of the farm as the main document certifying the identity of a citizen of the Russian Federation, or other identity document, if the applicant is a foreign citizen or a stateless person;

- the document on payment of the state fee. The state fee is 400 rubles (clause 8, clause 1, Article 333.33 of the Tax Code of the Russian Federation).

If the main identity document of the head of the farm does not contain information about his date and place of birth, place of residence, or he is a minor citizen, then you must also submit the relevant documents specified in sub-paragraphs " $d "$ " $z$ " of paragraph 1 of Article 22.1 of the Law on State Registration.

In addition, from the sheet " B "of the application form P21002, it follows that the application must be submitted and the agreement on the establishment of a farm, the conclusion of which is provided for in Article 4 of the Federal Law "On peasant (Farmer) Farming". Therefore, although the law does not contain such a requirement, we recommend that if a peasant (farm) farm is created by several persons, submit a copy of such an agreement to the registration authority.

In accordance with paragraph 2 of Article 22.1 of the Law on State Registration, the accuracy of copies of documents submitted during state registration must be notarized, except if the applicant submits it to the registration authority directly and simultaneously submits the corresponding document in the original to confirm the accuracy of such a copy. This original is returned to the applicant when the registration authority issues the receipt provided for in paragraph 3 of Article 9 of the Law on State Registration.

Statement and other documents filed by the head of farm in registering body directly or sent by mail with the declared value when forwarding a list of contents (section 1 of article 9 of the Law on state registration).

State registration is carried out within no more than five working days from the date of submission of documents to the registration authority (clause 3 of Article 22.1, clause 1 of Article 8 of the Law on State Registration). The decision on state registration made by the registering body is the basis for making the corresponding entry in the state register. No later than one working day from the date of state registration, the registering body issues (sends) the following documents:) to the applicant the certificate of state registration of the farm (p. 1 and p. 3 of Article 11 of the Law on State Registration, order of the Ministry of Internal Affairs of the Russian Federation of December 03, 2003 No. BG-3-09/664).

From this moment on, the head of the peasant (farmer) farm bears financial and legal responsibility, which consists in applying financial sanctions to offenders, which are measures of financial and legal coercion.

In 2000, more than 17 thousand farms were registered in the Rostov Region. In 2020, their number was reduced to 11 thousand. The decrease in the number of farms is accompanied by an increase in the area per farm, that is, they are being enlarged with a further 
transition to other forms of management. As noted, according to Rostovstat, a little more than 8.6 thousand farms or $77.6 \%$ of the number of registered land plots for farming work.

In 2019, the administration of the Oryol district of the Rostov Region held a competitive selection for grants for "Novice Farmers" and "Family Livestock Farms" and will continue to implement grant programs to support peasant (farm) farms.

The Ministry of Agriculture and Food of the Rostov Region planned to start the competitive selection of business plans of heads of peasant (farm) farms for 2021 from 01.12.2020. Dairy farming remains a priority sector in the implementation of grant programs, while in crop production - the cultivation of fruit and berry crops, grapes, and the creation of greenhouse complexes.

Since 2019, the maximum grant amount for novice farmers for the development of dairy farming has been up to 5.0 million rubles, for other areas - up to 3.0 million rubles. The grant amount for the development of family livestock farms in the dairy sector is 21.6 million rubles, for the meat sector (except for sheep and poultry farming) - 5.4 million rubles, for the development of sheep and poultry farming-up to 3.0 million rubles.

Large families that have registered a peasant (farm) farm can participate in the above programs.

Reference materials on the preparation of documents for competitive selection and the forms of necessary documents are available on the central page of the official website of the Ministry of Agriculture and Food of the Rostov Region www.don-agro.ru in the sections "Family farms" and "Novice farmers".

Thus, we can summarize that without the support of the state, the Russian farmer simply will not survive.

Decree of the Government of the Russian Federation No. 996 of August 25, 2017 approved the Federal Scientific and Technical Program for the Development of Agriculture for 2017-2025" (with amendments and additions of May 28, 2020).

The goal of the program is to ensure a stable growth in the production of agricultural products obtained through the use of seeds of new domestic varieties and breeding products( material), technologies for the production of high-quality feed, feed additives for animals and medicines for veterinary use, pesticides and agrochemicals of biological origin, processing and storage of products, raw materials and food, modern diagnostic tools, quality control methods and expertise of genetic material. The directions of the program implementation are defined. Among other things, it is planned to attract investments in the agro-industrial complex; to create and implement technologies for the production of seeds of the highest categories (original and elite) of agricultural plants, breeding products (material) in the areas of domestic crop production and animal husbandry, which currently have a high degree of dependence on seeds or breeding products (material) of foreign production. The total amount of funding for the events is $26,094.8$ million rubles.

As a result, it is expected to reduce import dependence through the introduction and use of new technologies in agriculture.

On the website of the Ministry of Agriculture and Food of the Rostov region https://donagro.ru the list of winners of the competitive selection for grants in support of novice farmers from 04.08.2020 was published. The competitive selection was carried out in the following categories:

Table 1. Categories, number of participants and amount of grants

\begin{tabular}{|c|c|c|}
\hline Category & $\begin{array}{c}\text { Number of } \\
\text { participants }\end{array}$ & $\begin{array}{c}\text { The actual amount } \\
\text { of the grant }\end{array}$ \\
\hline Dairy farming & $\begin{array}{c}14 \text { individual } \\
\text { entrepreneurs or peasant } \\
\text { (farm) farms }\end{array}$ & 64613930,00 \\
\hline
\end{tabular}




\begin{tabular}{|c|c|c|}
\hline Crop production & $\begin{array}{c}11 \text { individual } \\
\text { entrepreneurs or peasant } \\
\text { (farm) farms }\end{array}$ & 30965036,00 \\
\hline Meat farming & $\begin{array}{c}2 \text { individual } \\
\text { entrepreneur or the } \\
\text { peasant (farmer) } \\
\text { economy }\end{array}$ & 124688505,26 \\
\hline Total & - & 220267471,26 \\
\hline
\end{tabular}

According to the Strategy of socio-economic Development of the Rostov Region for the period up to 2030, the dynamics of the permanent population of the Rostov region in 20112018 is presented as follows:

Table 2. Permanent population as of January 1 (thousand people)

\begin{tabular}{|c|c|c|c|c|c|c|c|c|}
\hline $\begin{array}{l}\text { The name } \\
\text { of the } \\
\text { parameter }\end{array}$ & $\begin{array}{l}2011 \\
\text { year }\end{array}$ & $\begin{array}{l}2012 \\
\text { year }\end{array}$ & $\begin{array}{l}2013 \\
\text { year }\end{array}$ & $\begin{array}{l}2014 \\
\text { year }\end{array}$ & $\begin{array}{l}2015 \\
\text { year }\end{array}$ & $\begin{array}{l}2016 \\
\text { year }\end{array}$ & $\begin{array}{l}2017 \\
\text { year }\end{array}$ & $\begin{array}{l}2018 \\
\text { year }\end{array}$ \\
\hline 1 & 2 & 3 & 4 & 5 & 6 & 7 & 8 & 9 \\
\hline \multicolumn{9}{|c|}{ Permanent population as of January 1 (thousand people) } \\
\hline Rostov region & 4275.2 & 4260.5 & 4254.6 & 4245.5 & 4242.1 & 4236.0 & 4231.4 & 4220.5 \\
\hline $\begin{array}{l}\text { The share of } \\
\text { the Rostov } \\
\text { Region } \\
\text { (hereinafter } \\
\text { also - RO) in } \\
\text { the Russian } \\
\text { Federation } \\
\text { (hereinafter } \\
\text { also-RF) } \\
\text { (percent) }\end{array}$ & 2.99 & 2.98 & 2.97 & 2.96 & 2.90 & 2.89 & 2.88 & 2.87 \\
\hline $\begin{array}{l}\text { Place of RO } \\
\text { in the Russian } \\
\text { Federation }\end{array}$ & $6-e$ & $6-e$ & $6-e$ & $6-e$ & $6-e$ & $6-e$ & $6-e$ & $6-\mathrm{e}$ \\
\hline
\end{tabular}

According to the number of permanent population, the region consistently occupies the 6th place in Russia and 2nd place in the Southern Federal District, behind the Krasnodar Territory. The urban population accounts for 68.2 per cent. Accordingly, the share of the rural population is $31.8 \%$. The share of persons officially engaged in peasant (farm) farming is not more than $20 \%$. There are many private farms, but not all private owners are eager to officially become farmers. You need to register as an individual entrepreneur and pay more taxes. The question of how much personal production of agricultural products "for themselves" turns into commercial production is also a hot topic of discussion. This issue remains outside the legal field for the time being. Today, it is more profitable to run a private subsidiary farm than to be a farmer. But farmers and private owners have a common problem: they are being pushed out of the market by large agricultural holdings. It is easier for them to get development loans and find sales markets. As a result, the farmer is squeezed into a competitive framework between large and small farms. But the market, there is a market. Survival of the fittest. Russia has adopted the program "Integrated development of rural areas". In the next five years, the country's regions should receive a trillion rubles from the federal budget for the development of villages. 
Over the past decade, Rostov region of the Southern Federal District in Russia has experienced a major reduction in agricultural production due to climate variability and imperfect institutional mechanisms. Rural communities and agricultural producers, especially in small and medium scale businesses, have been affected by climate change and human-induced disasters in the form of drought, floods, and unusual hot and cold weather [5].

As a result, it is necessary to use an economic and legal approach when developing contract terms for the delivery of goods, taking into account the norms of international law, the national legislation of the supplier country and in accordance with the calculations of the contract price and payment terms [6].

It is determined that in modern Russia (2019) the consumers pay a lot of attention to the indicators of innovations during determination of quality of goods and services. Consumers' opinion is taken into account in modern Russia. Quality of the considered goods and services in 2019 grew, as compared to 2015, due to improvement of their innovative characteristics. Based on this, it is recommended-in the mid-term-to continue the set course of state and corporate management of quality of goods and services in Russia and to pay more attention to improvement of their innovative characteristics $[7,8]$.

One of the objectives of the program is to increase the rural population. Throughout the country, it should make up at least a quarter of the total population of the country. In the Rostov region, this indicator has already been exceeded: today, $32 \%$ of the population of the Don is rural. Now the main thing is to maintain this level and make people's lives more comfortable. According to the results of the last agricultural census, the Rostov region ranks fourth - in the number of peasant farms and in the number of personal subsidiary farms of the population, and third - in the number of agricultural organizations.

The Rostov region is actively developing interdisciplinary and branch scientific institutions that can contribute to the development of the peasant (farmer) economy, including:

The Southern Scientific Center of the Russian Academy of Sciences;

The Federal State Budgetary Scientific Institution "Agrarian Scientific Center" Donskoy "(hereinafter - FGBNU "ANC "Donskoy")

The federal State budgetary scientific institution "Federal Rostov Agrarian Scientific Center" (FGBNU FRANTS);

The Russian Research Institute of Land Reclamation Problems;

All-Russian Research Institute of Meat Industry named after V. M. Gorbatov;

The North Caucasus Zonal Research Veterinary Institute.

The modern farmer should be focused on global trends, which of course need to be considered in a complex - this is climate change, a change in the food model and the market for healthy food products that the urban population needs.

It could be convergence (simultaneous utilization during the same entrepreneurial processes with the emphasis on unique features by the terms of the competition) or divergence (usage during different business processes by the terms of labor division $[9,10]$.

\section{Conclusion}

Peasant (farm) economy - a type of business activity and an association of citizens who jointly own property and carry out production or other economic activities. After the state registration of a peasant farm, its Head is an individual entrepreneur-farmer. The property of a farm belongs to its members on the right of joint ownership. 
Participants in civil turnover have the right to enter into obligations that are not directly provided for by law, but most fully meet their individual needs, including to conclude contracts that are not directly provided for by civil law [11].

The problem is that there is no legal possibility to take out a subsidized loan if a legal entity or a peasant (farmer) farm has been registered for less than one year. Incoherent support is almost useless, as it requires crop insurance, which negates all its advantages. The lack of additional incentives for the younger generation to conduct agricultural activities, to replace them, leads to the lack of implementation of these norms in practice. The decrease in the number of farms is accompanied by an increase in the area per farm, that is, they are being enlarged with a further transition to other forms of management. The situation is complicated by the low profitability of peasant farms, which destroys farming, while it is small farms that ensure both the growth of livestock and the annual increase in grain production. This is a big problem that needs to be addressed urgently through government support. State support should develop evenly, on a fair basis, and not only in favor of large vertically integrated holdings.

Since 2019 the maximum grant amount for novice farmers for the development of dairy farming in the Rostov region has been up to 5.0 million rubles, for other areas up to 3.0 million rubles. The grant amount for the development of family livestock farms in the dairy sector is 21.6 million rubles, for the meat sector (except for sheep and poultry farming) - 5.4 million rubles, for the development of sheep and poultry farming-up to 3.0 million rubles. The size of the grants is not enough to develop the farming movement and stimulate the expansion of production. Farmers urgently need short soft loans, an increase in the limit of microfinance funds to 10 million rubles. There is also a need to introduce leasing holidays, reduce tariffs for paying for veterinary work, and for electricity. Today, there is a new format of farmers-urban residents who move to the village and are engaged in farming. They need support, both financial and legal, and informational. According to the Decree of the Government of the Russian Federation, from 2020, the rate of 3\% for the purchase of housing in rural areas is valid. A program has also been adopted for the purchase or construction of housing in rural areas. Exceptions are Moscow, the Moscow Region and St. Petersburg. There are no requirements for the age and marital status of the borrower. For the Far East, the Yamalo-Nenets Autonomous territory and the Leningrad Region, the maximum loan amount at a preferential rate is 5 million rubles, for other regions-up to 3 million rubles. The mortgage term is up to 25 years, the minimum payment is $10 \%$.

2020 was the final year for the program "How to become a farmer from scratch". In 2012 in Russia launched a long-term Program "How to become a farmer from scratch", aimed at the development of the agriculture sector (Decree of the RF Government dated 14.07.2012 № 717 Law No. 74-FZ "On peasant (farmer) economy"). The main goal of the new policy was for the period from 2013 to 2020 inclusive to increase the number of farms and improve the productivity of the national agricultural sector. As part of the implementation of these goals, it was necessary to develop an effective algorithm for how to become a farmer from scratch. Subsidies and grants from the state were supposed to help in this. However, bureaucratic mechanisms have practically nullified this program, and the number of farms has decreased by almost $50 \%$.

A promising direction for the development of farms is the association in cooperatives. In the Rostov region 68 cooperatives are registered, of which 6 were created in 2020.

An agro-town will support to national economy, making goods and thus using technology of the Russian production and introducing a ready-made product to the market with worthy quality cultivating attachment and trust to its own product in potential consumers. The main advantage of an agro-town is solution of the problem of sale of agricultural products on reasonable prices which at the moment cannot be fixed due to the lack of relevant institutes 
(integrity of buyers, transparency of the market). The fair price in this case is defined at the agro-exchange house which is created along with an agro-town [12].

In the conditions of a prolonged financial and economic crisis, limited volumes and forms of state support for agricultural production, maintaining structural imbalance and inequality of intersectoral exchange, the development of vertical integration processes is a priority in improving the competitiveness of the Russian agro-industrial complex. Vertically integrated corporations (VIC) have the potential to ensure the proportional development of the areas of territorial agribusiness, innovative modernization of production assets of agricultural producers, agro-processing structures [13].

As a priority project for the development of the agro-industrial complex, financed on the basis of the state budget, the project of creating a multifunctional center should be noted. Its structure provides for the creation of an information and advisory center, a trade and service center, a plant for packaging and processing of fruit and vegetable products. To develop the export of grain products of the Republic of Adygea, agricultural producers are recommended to become a member of the "Trading Platform IDK.RU", in which the necessary amount of grain is purchased in the form of auctions, which take place every day for half an hour. Among the regions of the Southern Federal District, the participants of this trading platform are: Astrakhan Region, Volgograd Region, Krasnodar Territory, Rostov Region.

The potential of financial and legal responsibility is not the only one in solving all these problems: other legal and institutional factors play a significant role. At the same time, for the purposes of building a legal tax state, with clearly defined characteristics of the financial activities of the state of formation, the development of financial and legal responsibility is of the most important purpose [14].

In accordance with the Strategy of Socio-economic Development of the Republic of Adygea until 2030, it is planned to implement the flagship project "Agro-industrial Cluster of the Republic of Adygea" which includes the creation of agro-food and meat and dairy subclusters. The implementation of the cluster approach is aimed at the formation and development of quasi-integration relations, the implementation of a unified financial and marketing policy of the cluster residents, as well as the promotion of regional agri-food brands.

Of great importance in the implementation of agricultural activities is the preservation of the environment. Social relations mediate the functioning of the "man - environment" system, including both the use of natural resources and the purposeful impact of man on nature in order to preserve and increase it [15].

\section{References}

1. V. Kuznetsova, D. Kondusov, A. Serdyuk, A. Sergeev, Russian engineering research 10, 892-896 (2017) doi: 10.3103/S1068798X17100136

2. E. Cherkesova, E. Grevtseva, N. Demidova, A. Suhova, Journal of advanced research in law and economics 6(3), 543-550 (2015) doi: 10.14505/jarle.v6.3(13).09

3. J. Gornostaeva, I. Kushnaryova, N. Tregulova, Journal of entrepreneurship in emerging economies 10(3) (2018) doi: 10.1108/JEEE-12-2017-0100

4. M. Malkina, T. Economicus 16(3), 118-131 doi: 10.23683/2073-6606-2018-16-3-118130

5. S. Shokri, A. Arkhipov, O. Belokrylova, Y. Filonenko, The world of Russia 26(2), 82102 (2017)

6. T. Skvortsova, G. Pratsko, J. Isakova, V. Sevumyan, Internation journal of economics and business administration 8, 395-403 (2020) DOI: 10.35808/IJEBA/433 
7. E. Popkova, A. Giyazov, In the book: Growth Poles of the Global Economy: Emergence, Changes and Future Perspectives. Cep. "Lecture Notes in Networks and Systems" Plekhanov Russian University of Economics. (Luxembourg, 2020)

8. E. Popkova, B. Sergi, Journal of Intellectual Capital 21(4), 565-581 (2020) doi: 10.1108/JIC-09-2019-0224

9. E. Popkova, International Journal for Quality Research 14(2), 329-346 (2020) doi: 10.24874/IJQR14.02-01

10. E. Popkova, I. Morozova, The international entrepreneurship and management journal 15(2), 589-597 (2019) DOI: 10.1007/s11365-018-0522

11. N. Antonova, E. Lunyova, Journal of advanced research in law and economics 8(3), 708713 (2017) doi: 10.14505/jarle.v8.3(25).02

12. V. Prokhorova, E. Zakharova, A. Gladilin, A. Molchan, International Review of Management and Marketing 6(S6), 191-196 (2016)

13. A. Mokrushin, V. Prokhorova, V. Aluyan, S. Savvidi, International journal of recent technology and engineering 8(4), 6135-6139 (2019) doi: 10.35940/ijrte.D8878.118419

14. L. Barashyan, International Review of Management and Marketing 6(S6), 235-240 (2016)

15. O. Grechenkova, Journal of advanced research in law and economics 8(3), 821-828 doi: 10.14505/jarle.v8.3(25). 15 